\title{
Money Laundering Crime and Its Situational Prevention in Iranian Law and International Law
}

\author{
Farzad Sohraby ${ }^{1}$, Hossein Habibitabar ${ }^{1} \&$ Mohammad Reza Masoudzade ${ }^{1}$ \\ ${ }^{1}$ College of Human Science, Saveh Branch, Islamic Azad University, Saveh, Iran \\ Correspondence: Farzad Sohraby, College of Human Science, Saveh Branch, Islamic Azad University, Saveh, \\ Iran. E-mail: sohraby.farzad@gmail.com
}

\author{
Received: May 4, 2016 Accepted: May 27, 2016 Online Published: August 11, 2016 \\ doi:10.5539/jpl.v9n7p57 URL: http://dx.doi.org/10.5539/jpl.v9n7p57
}

\begin{abstract}
Crime prevention is crucial to social life which necessitates the need for conducting criminology studies to identify the causes of the crime. In this paper, we focus on money laundering crime. First we discuss about money laundering crime in Iran's penal system, and after presenting its criminological characteristics (transnational, organized and victimless), we review Iran's legal system and the international conventions about this crime. Then, since major situational prevention measures against money laundering are related to the banks and financial institutions, we proposed some measures for financial institutions such as staff training, adjusting banking secrecy laws, monitoring money transfer, reporting large cash transactions, and reporting suspicious transactions. Results showed that Iran's anti money laundering laws are in accordance with Merida convention, for example, in terms of identification, record-keeping and the reporting, but do not obligate the identification of customer when there is criminal evidence.
\end{abstract}

Keywords: money laundering, Iranian law, international law, AML

\section{Introduction}

Money laundering happens in almost every country in the world. In money laundering, on one hand, we face a crime that has some proceeds which should be laundered, and on the other hand, we encounter with possible crimes that may be occur after the money laundering. Therefore, preventing from money laundering can lead to preventing from predicate offenses and posteriori offense. Private banks, loan and credit institutions, brokers \& stock dealers, insurance companies, foreign exchange dealers, gold and silver dealers are some of the institutions that are prone to money laundering. Money laundering is a process whereby the proceeds of crime are transformed into apparently legitimate money or other assets. Nowadays, criminalization of money laundering for the prevention of predicate offenses has attracted the attention of international conventions and national legislation. in the introduction of UNCC, it has been stated that: “... concerned about the links between corruption and between corruption and other forms of crime, in particular organized crime and economic crime, including money laundering, ... determined to prevent, detect and deter in a more effective manner international transfers of illicitly acquired assets and to strengthen international cooperation in asset recovery" . As can be seen, it has indicated the relationship between money laundering and drug-related crimes and corruption. If the incentive of gaining illegal income be one of the principal causes of crime by economic offenders, criminalization of money laundering can mitigate dilution of incentives for these groups of criminals (Saki, 2008). For example, the majority of thieves commit robbery in hopes to be able to convert the stolen property to money, so, the most effective way to combat robbery is to prevent from buying and selling stolen properties. In fact, since the buyers of stolen properties keep the incentive of theft alive for thieves, they have a great responsibility (Mir Mohammad Sadeghi, 2003).

Due to the absence of direct victim in money laundering crime, there is a need for seeking alternate entities to take supportive acts. For this purpose, according to United Nations Convention against Transnational Organized Crime (UNCTOC) (Palermo convention), the states shall institute a comprehensive domestic regulatory and supervisory regime for banks and non-bank financial institutions like beneficial owner identification, keeping records and reporting suspicious transactions. In this regard, Financial Action Task Force (FATF) was formed in 1989 to develop and promote international cooperation for combating money laundering in international level. In Iran, under the article of 38 of the executive bylaw of national anti-money laundering act (AML) a Financial 
Intelligence Unit, a centralized and independent unit, has been established which is responsible to receive, analyze and refer the reports about suspicious transactions to the competent authorities.

There are many national and international studies that have addressed the crime of money laundering (e.g.; Bartlett, 2002; Aldridge, 2008; Arnone \& Borlini, 2010; Moghimi Mofrad \& Heidari, 2014). Araujo (2010) showed that the efficiency of anti-money laundering combat relies on the conjugation of factors such as a proper design of the anti-money laundering regulation and an endogenous willingness of banks and workers to cope against this war. Van Wyk (2001) in his study about fighting against money laundering in South Africa concluded that effective money laundering prevention is recognition.

Given the particular characteristics of the crime of money laundering, the main measures foreseen to prevent it, is a kind of situational prevention. Situational crime prevention (SCP) first was presented and developed by Clarke and his colleagues (Clarke, 1980; Clarke \& Mayhew, 1980; Cornish \& Clarke, 1986). It is a set of managerial and environmental measures to reduce the opportunity for those crimes to occur: "it is focused on the settings for crime, rather than upon those committing criminal acts. It seeks to forestall the occurrence of crime, rather than to detect and sanction offenders. It seeks not to eliminate criminal or delinquent tendencies through improvement of society or its institutions, but merely to make criminal action less attractive to offenders" (Clarke, 1997). Nowadays, SCP is an appropriate method for the prevention of serious crime types, including: organized crimes (Bullock, Clarke \& Tilley, 2010), terrorism (Clarke, 2009) and fraud (Smith et al., 2011). According to the conducted studies in SCP which include residential burglary (Wright; Logie \& Decker, 1995), robbery (Walsh, 1986) and organized crime (Cornish \& Clarke, 2002), money laundering may now be another appropriate choice for its application. Given this, Gilmour (2013) studied the applicability of situational prevention of money laundering in UK through intensive business and purchase of high value portable commodities and found that these methods are susceptible to money laundering. In domestic laws and regulations of Iran, SCP against money laundering has been confronted with some problems and obstacles which are going to be investigated in this study. In Iran, the crimes which need money laundering are drug trafficking, goods smuggling, illegal imports, embezzlement, fraud, bribery, forgery and false accounting (Saki, 2008). Study of the SCP against money laundering can compensate for the lack of attention to this topic in the legal doctrine of Iran, and with revealing the weaknesses of the AML act, can help in modifying the law in Iran. In this paper we seek to answer to following questions:

(1). What are the measures of SCP against money laundering?

(2). Is SCP against money laundering has been addressed in Iran's anti-money laundering act?

\section{Literature Review}

\subsection{Money Laundering}

Money laundering as one of the macro-economic organized crimes which has been addressed in the in the United Nations Convention against Corruption (UNCC) (Merida Convention), simply is described as a process by which criminals disguise the original ownership and control of the proceeds of criminal conduct by making such proceeds appear to have derived from a legitimate source. According to the United States Treasury Department, "Money laundering is the process of making illegally-gained proceeds (i.e. "dirty money") appears legal (i.e. "clean"). Typically, it involves three steps: placement, layering and integration. First, the illegitimate funds are furtively introduced into the legitimate financial system. Then, the money is moved around to create confusion, sometimes by wiring or transferring through numerous accounts. Finally, it is integrated into the financial system through additional transactions until the "dirty money" appears "clean." International Criminal Police Organization (INTERPOL) defines money laundering as: "any act or attempted act to conceal or disguise the identity of illegally obtained proceeds so that they appear to have originated from legitimate sources". Under article 2 of Iranian AML act, it is consists of (a) acquisition, possession, keeping or using the proceeds from illegal activities with the knowledge that they have been acquired directly or indirectly through a criminal offence, (b) change, exchange, or transfer of proceeds with the intention of hiding their illegal origin with knowledge that they have been acquired directly or indirectly through a criminal offence, or helping the offender in such a way that the legal effects and consequences of the commitment of that crime would not involve him/her, and (c) hiding or covering up the real nature, origin, source, location, movement, displacement, or possession of proceeds obtained directly or indirectly as a result of an offence. Article 3 also defines "Proceeds of crime" as any property obtained directly or indirectly from criminal activities". There are three main methods by which criminal organizations move money for the purpose of disguising its origins and integrating it into the formal economy. The first is through the use of the financial system; the second involves the physical movement of money (e.g. through the use of cash couriers); and the third is through the physical movement of goods through 
the trade system.

\subsection{The Criminological Characteristics of Money Laundering}

Since any crime prevention requires understanding the characteristics of that crime, in this section, we explain the three criminological characteristics of money laundering including being transnational, organized and victimless. (Babaei Kanglu \& Rostami Ghazani, 2010)

A. Organized crime: Organized crimes are types of crimes which are associated with a kind of organizational discipline run in a group. According to UNCTOC, "organized criminal group" shall mean a structured group of three or more persons, existing for a period of time and acting in concert with the aim of committing one or more serious crimes or offences established in accordance with this Convention, in order to obtain, directly or indirectly, a financial or other material benefit". In an organized criminal group, a variety of crimes are committed where money laundering is usually one of them.

B. Transnational crime: Transnational crimes are crimes that have actual or potential effect across national borders and crimes which are intra-state but which offend fundamental values of the international community. So, if, for some reasons, a crime is related to more than one country, it will have a transnational aspect. In this regard, it should be said that money laundering is not necessarily a transnational crime but day by day, the number of money launderings which have transnational aspect is increasing. Considering the place of predicate offenses and place of money laundering, there are four cases. Sometimes both offenses are committed inside the country, here; we are faced with an inter-state money laundering. Sometimes the predicate offense is committed inside the country but the crime of money laundering is committed outside the country. In this case, it is called intra-state money laundering. Also, the predicate offense may be committed outside the country and money laundering inside the country which is called imported money laundering, and finally both offenses may be committed outside the country; in this case we name it abroad money laundering. From these, only intra-state and imported types have transnational aspect. Preventing from transnational money laundering requires international cooperation. In this regards, FATF in 1990 developed recommendations to combat money laundering. Also article 14, paragraph 4 of UNCC stated that "In establishing a domestic regulatory and supervisory regime under the terms of this article, and without prejudice to any other article of this Convention, States Parties are called upon to use as a guideline the relevant initiatives of regional, interregional and multilateral organizations against money-laundering.", and under paragraph 5, " the States Parties shall endeavour to develop and promote global, regional, sub-regional and bilateral cooperation among judicial, law enforcement and financial regulatory authorities in order to combat money-laundering."

C. Victimless crime: it is a term used to refer to actions that have been made illegal but which do not directly violate or threaten the rights of any other individual. It often involves consensual acts, or solitary acts in which no other person is involved. Such acts would not lead to any person calling for help from the police, so, it raises delinquency. The crime of money laundering has no exception to this, and therefore its detection is decreased by the absence of the complaint parties.

\section{Money Laundering Crime in Iran's Penal System}

In 2003, the Merida Convention was adopted by the UN General Assembly. In this Convention, articles 14, 23 and 52 emphasize taking measures to prevent from money laundering. Iran joined to this convention on 2008 by the approval of Majma-e-Tashkhis-e-Maslahat-e Nezam (Expediency Discernment Council of the System). One year before it, Iran had approved Anti-Money Laundering Law. Article 9 of this act states that: "Those who engage in the crime of money laundering will, in addition to returning the assets and the proceeds derived from the crime comprising the original assets and the profits there of (and if nonexistent, the equivalent or the price), be sentenced to a fine of one fourth of the value of the proceeds of the crime which should be deposited into the public Revenues Account with the Central Bank of the Islamic Republic of Iran". This article has three clauses:

- Clause 1: If the proceeds have been transformed or changed into other property, the said property will be seized.

- Clause 2: The order to seize the assets and their derived profits can be issued and exercised if the accused has not been subject to this order under predicate offences.

- Clause 3: If those who commit predicate offences also commit money laundering in addition to being sentenced for the offence committed, they will be subject to the punishments set out in this law.

The important point about this article is the lack of proportionality between crime and punishment. Iranian AML Law has considered a fixed punishments and one fourth of the value of the crime proceeds, while the judge 
should have enough discretion to mete out the punishment considering the degree of the offense and the type of money laundering. The punishment of paying one fourth of the value of the proceeds is disproportionate (Kousha, 2008). Therefore, the punishment for money laundering in Iranian law can be criticized from two aspects: (1) the legislator has determined fixed punishments but considered no discretion for judges for the individualization of punishment; (2) the amount of the predicted punishment does not fit the severity of crime. If we agree that the person who makes decision to commit a crime, in practice, acts as an economist who weighs up the advantages and disadvantages of the crime, proportionality between crime and punishment becomes obvious (Pradel, 1994). This theory which is based on the thoughts of the thinkers like Bantham and Feuerbach, believes that in order that severity of punishment become a decisive motive of behavior, the punishment should be slightly higher than the pleasure that the criminal hopes to gain by committing the criminal act (Najafi Abarandabadi \& Hashem Beigi, 1998). Although no certain measure can be determined for the proportionality between the offense and punishment, but a civil judgment can be useful. What was mentioned in the criticism of article 9 of Iranian AML act is a criticism of the criminal prevention of money laundering is related to both general and specific deterrence of punishment. Although deterrence by punishment in addition to the severity of punishment is also based on the speed and certainty of punishment (Williams \& McShane, 1998), however, the severity of proportionality is necessary.

\section{Measures for SCP against Money Laundering}

In the criminal policy of Iran and the United Nations, some measures have been predicted that are both criminally and non-criminally qualified. Non-criminal measures are self-driven, society-driven or situation-driven. In this study, only the most prominent situational preventive measures against economic crimes are mentioned. To prevent from money laundering, it is necessary to identify money laundering markets. Undoubtedly, partial proceedings of crime have the capability to be laundered in everyday transactions and to meet the necessities of life, so prevention of such types of money laundering is difficult. Large volumes of money laundering require an entry in the financial markets and investment. In this regard, banks and credit institutions are of great importance, because (1) since banks and financial institutions are equipped with modern communication technology, the fast transfer without a physical presence has been possible, (2) The enormous volume of transactions does not give the bank an opportunity to review and analyze the transfers, (3) Criminals can launder money through the Internet outside of the country (Moradi, 2009). So, according to what was said, major situational prevention measures against money laundering are related to financial institutions and banks. Following we discuss about these measures.

\subsection{Staff Training}

To prevent from any type of crime, particularly organized crimes, it is necessary to train employees and officers who somehow deal with the considered crime. Therefore, under article 7, paragraph $(e)$ of Iranian AML act, banks, financial and credit institutions, insurance companies, charities, etc. are obligated to establish internal control measures and train managers and personnel in order to comply with the provision of the law and its by-laws. The success of measures and other actions depend on necessary and sufficient trainings.

\subsection{Adjusting Banking Secrecy Laws}

Banks and financial institutions traditionally try to maintain confidentiality of customers but in some cases, this can result in money laundering detection failure. Accordingly, article 40 of UNCC states that: "Each State Party shall ensure that, in the case of domestic criminal investigations of offences established in accordance with this Convention, there are appropriate mechanisms available within its domestic legal system to overcome obstacles that may arise out of the application of bank secrecy laws".

\subsection{Monitoring Money Transfer}

Authentication of applicants for banking services plays an important role in the prevention of money laundering. By detecting them and monitoring the movement of cash, the possibility of money laundering detection will increase. In this regard, article 14, paragraph 3 of UNCC says that: "States Parties shall consider implementing appropriate and feasible measures to require financial institutions, including money remitters:

(a) To include on forms for the electronic transfer of funds and related messages accurate and meaningful information on the originator;

(b) To maintain such information throughout the payment chain; and

(c) To apply enhanced scrutiny to transfers of funds that do not contain complete information on the originator.

According to bylaw of cash flow documentation in Iran adopted by the member of ministers in 2008, the same rules have been mentioned and based on its article 1, paragraph (a), it says that providing banking services to its 
customers is subject to their identification.

According to Article 7 of Iran's AML act:" Individuals and organizations subject to this law (subjects of Articles 5 and 6) are obligated to observe the following points based on their type of activity and organizational structure:

i. Verification of the identity of the client, and where relevant verification of the identity and relationship of the client's representative or proxy, as well as verification of the identity of the principal, in case there are evidences of offence;

Clause: approval of this law does not contradict the cases required in other rules and regulations related to the identity verification.

ii. Provision of information, reports, documents, and evidence to the Anti-Money Laundering High Council within the by-law approved by the Council of Ministers.

iii. Reporting of suspicious transaction and operations to a competent authority as designated by Anti-Money Laundering High Council

iv. Maintenance of records on client identification, account history, operations and transactions as long as determined in the executive by-law.

v. Establishing internal control measures and training managers and personnel in order to comply with the provision of the law and its by-laws.

\subsection{Reporting Large Cash Transactions}

According to this measure, cash transactions whose value is greater than the amount specified by the competent authorities should be reported. Article 14, paragraph 2 of UNCC stipulates that "States Parties shall consider implementing feasible measures to detect and monitor the movement of cash and appropriate negotiable instruments across their borders, subject to safeguards to ensure proper use of information and without impeding in any way the movement of legitimate capital. Such measures may include a requirement that individuals and businesses report the cross-border transfer of substantial quantities of cash and appropriate negotiable instruments". According to this measure, article 7 of Cash Flow Documentation bylaw of Iran stipulates that: in order to secure the public assets of the general public referred to in article 1, the Central Bank of the Islamic Republic of Iran is obligated to prohibit cash payments (cash, bank cheque and Iranian cheque) more than 50000000 Rials everyday and for every account by one year after the notification of this regulation.

\subsection{Reporting Suspicious Transactions}

Another measure which can be taken into consideration to combat money laundering is to report the suspicious transactions to the competent institutions. Under article 1, paragraph 7 of Iran's Directive on Identification of Suspicious Transactions and Method of Reporting passed by the Ministers of the Working Group for the Adoption of implementing regulations of the AML act, suspicious transactions are "transactions and activities which persons, having access to information and/or reasonable grounds, suspect are being performed with the aim of money laundering". Article 14, paragraph (a) of UNCC stated that "Each State Party shall institute a comprehensive domestic regulatory and supervisory regime for banks and non-bank financial institutions ...in order to deter and detect all forms of money-laundering, which regime shall emphasize requirements for customer and, where appropriate, beneficial owner identification, record-keeping and the reporting of suspicious transactions."

\section{Conclusion}

Crime prevention has been necessary for social life from the long past which has existed in different forms in different societies. In this regard, preventing from the offense of money laundering is no exception. Money laundering causes irreparable and harmful social, cultural, political and economic damages to the country's economy. For this reason Merida convention was formed in 2000. Money laundering has been criminalized under Iranian AML Law of 2007, and prior to this time, Iran by joining or signing various conventions such as United Nations Convention Against Illicit Traffic in Narcotic Drugs and Psychotropic Substances, United Nations Convention on Transnational Organized Crime, and United Nations Convention against Corruption had shown its willingness to criminalize the offense of money laundering and consequently prevent it. By considering the relationship between money laundering crime and the predicate offenses on one hand, and the offenses that may occur after money laundering on the other hand, the necessity and importance of money laundering prevention becomes evident. Therefore, by recognizing the criminological characteristics of money laundering such as being organized, transnational and victimless, some measures can be taken to prevent from it. By reviewing international conventions and national laws of Iran, it can be understood that the main measures taken to prevent from money laundering are situational which attempts to prevent from money laundering by making it difficult to commit and increasing the probability of detection. Since prevention measures applied by 
various institutions in Iran, it requires coordination for efficiency. For this purpose, In Iran's AML act, Supreme Council of the Anti-Money Laundering was formed which has its own challenges.

In this study, by reviewing Iran's legal system and the conventions about money laundering crime, it was concluded that first, although Iran's Monetary and Credit Council's instructions are adopted and implemented before the adoption of these conventions, its law is in accordance with Merida convention for example in terms of identification, record-keeping and the reporting, but on the other hand, Iran's AML law which was approved after the mentioned conventions, has ignored their provisions and obligation about the identification of customer in case of the existence of crime evidence. Second, the procedure lay down in article 7, paragraph (a) of Iranian AML act may cause crime and pave the way for committing the offense of money laundering, because they do not obligate the identification of customer when there is crime evidence. In this research we provided some measures for financial institutions to prevent from of money laundering according to national and internationals laws including staff training, adjusting banking secrecy laws, monitoring money transfer, reporting large cash transactions, and reporting suspicious transactions. By these methods, we can hope criminal activities related to money laundering be reduced.

\section{References}

Aldridge, P. (2008). money laundering and globalization. Journal of Law and Society, 35(4), 437-463. http://dx.doi.org/10.1111/j.1467-6478.2008.00446.x

Araujo, R. A. (2010). An evolutionary game theory approach to combat money laundering. Journal of Money Laundering Control, 13(1), 70-78. http://dx.doi.org/10.1108/13685201011010236

Arnone M., \& Borlini, L. (2010). International anti - money laundering programs. Journal of Money Laundering Control, 13(3), 226-271. http://dx.doi.org/10.1108/13685201011057136

Babaei Kanglu, J., \& Rostami Ghazani, O. (2010). Pishgiri az Jorme Polshouei ba Negahi be Siasate Jenaei Taghninie Iran [Prevention of Money Laundering according to the Legislative Criminal Policy In Iran]. Karagah, 10, 109-131. (In Persian)

Bartlett, B. L. (2002). The negative effects of money laundering on economic development. Platypus Magazine, $77,18-23$.

Bullock, K., Clarke, R. V., \& Tilley, N. (2010). Situational Prevention of Organised Crimes. Abingdon, United Kingdom: Willan

Central Bank of the Islamic Republic of Iran. (2007). Anti-Money Laundering Law. Retrieved from http://www.cbi.ir/page/5320.aspx

Clarke R. V. G., \& Mayhew, P. M. (1980).Designing out crime. London: HMSO.

Clarke, R. V. G. (1980). Situational crime prevention: theory and practice. British journal of criminology, 20(2), 136-148.

Clarke, R. V. G. (1997). Situational Crime Prevention: Successful Case Studies. NY: Harrow and Hesteon.

Clarke, R. V. G. (2009). Situational crime prevention: Theoretical background and current practice. In Krohn, M. D., Lizotte, A. J., \& Hall, G. P. (Eds.), Handbook on Crime and Deviance. New York: Springer Science and Business Media. http://dx.doi.org/10.1007/978-1-4419-0245-0_14

Cornish D. B., \& Clarke R. V. G. (1986). Situational prevention: displacement of crime and rational choice theory. In K. Heal, \& G. Laycock (Eds.), Situational crime prevention: from theory into practice. London: HMSO.

Cornish, D., \& Clarke, R. V. (2002). Analyzing Organized Crimes. In A. Piquero, \& S. Tibbetts (Eds.), Rational Choice and Criminal Behaviour. London: Routledge.

Gilmour, N. J. (2013). Improving the prevention of money laundering in the United Kingdom - a situational crime prevention approach. PhD thesis, University of Portsmouth, UK.

Islamic Republic Of Iran's High Council On Anti-Money Laundering Secretariat Financial Intelligence Unit. (2009). Directive on Identification of Suspicious Transactions and Method of Reporting. Retrieved from http://iranaml.com/en/?p=369

Kousha, J. (2008). Naghshe Dadsetan dar Mobareze ba Polshoei [The Role of Prosecutor to combat Money Laundering]. Khabarnameye Anjomane Irani Hoghoghe Jaza-Newsletter of Iranian Association of Penal Law. $\quad 9 \quad$ and $\quad 10 . \quad$ (In $\quad$ Persian) $\quad$ Retrieved from 
http://www.persianapl.ir/ArticleRecentPenalNewsLetter/DetailsUsers.aspx?ID=11

Mir Mohammad Sadeghi, H. (2003). Hoghoghe Keyfarie Ekhtesasi [Specific Criminal Law] (10 $0^{\text {th }}$ ed., vol. 2), Tehran: Mizan. (In Persian)

Moghimi Mofrad, S., \& Heidari, S. (2014). Investigation Of Money Laundering Crimes Comparative Study Between Iran And The International Documents. International Journal of Current Life Sciences, 4(8), 4098-4107.

Moradi, V. (2009). Siasate Jena'eye Iran dar Ghebale Jaraeme Polshouei va motale'eye Tatbighi dar Asnade Beynolmelali [Iran's Criminal Policy Against money Laundering Offenses and Comparative Study of International Documents]. Unpublished Master thesis, Central Tehran Branch, Islamic Azad University, Tehran, Iran. (In Persian)

Najafi Abarandabadi, A. H., \& Hashem Beigi, H. (1998). Daneshnameye Jorm Shenasi [Encyclopedia of Criminology]. Tehran: Shahid Beheshti University Press. (In Persian)

Pradel, J. (1994). Tarikhe Andishehaye Keyfari [History of criminal thoughts]. Translated to Persian by Najafi Abrandabadi, S.H. Tehran: SAMT.

Saki, M. R. (2008). Ashnaei ba Jorme Polshouei [Understanding the crime of Money Laundering] (1st ed.).Tehran: Javedaneh. (In Persian)

Smith, G., Button, M., Johnston, L., \& Frimpong, K. (2011). Studying fraud as white-collar crime. London: Palgrave Macmillan.

United Nations Office on Drugs and Crime. (2000). United Nations Convention against Transnational Organized Crime, NY: UN. Retrieved https://www.unodc.org/documents/middleeastandnorthafrica/organised-crime/UNITED_NATIONS_CONV ENTION_AGAINST_TRANSNATIONAL_ORGANIZED_CRIME_AND_THE_PROTOCOLS_THERET O.pdf

United Nations Office on Drugs and Crime. (2003). United Nations Convention Against Corruption. NY: UN. Retrieved from https://www.unodc.org/documents/brussels/UN_Convention_Against_Corruption.pdf

United Nations. (1998). United Nations Convention Against Illicit Traffic in Narcotic Drugs and Psychotropic Substances. NY: UN. Retrieved from https://www.unodc.org/pdf/convention_1988_en.pdf

Van Wyk, R. (2001). Current situation and countermeasures against money laundering in South Africa. $117^{\text {th }}$ International Seminar, United Nations Asia and Far East Institute for the Prevention of Crime and the Treatment of Offenders (UNAFEI), December 2001, Tokyo, Japan.

Walsh, D. (1986). Heavy business: commercial burglary and robbery. London: Routledge \& Kegan Paul.

Williams, F. P., \& McShane, M. D. (1998). Criminology Theory: Selected Classic Readings. Andra upplagan, Cincinnati: Anderson Publishing.

Wright, R., Logie, R., \& Decker, S. (1995). Criminal Expertise and Offender Decision Making: An Experimental Study of the Target Selection Process in Residential Burglary. Journal of Research in Crime and Delinquency, 32(1), 39-53. http://dx.doi.org/10.1177/0022427895032001002

\section{Copyrights}

Copyright for this article is retained by the author(s), with first publication rights granted to the journal.

This is an open-access article distributed under the terms and conditions of the Creative Commons Attribution license (http://creativecommons.org/licenses/by/4.0/). 